\title{
MODERN TECHNOLOGIES OF TEACHING ENGLISH LANGUAGE OF STUDENTS OF PEDAGOGICAL SPECIALTIES
}

The article is devoted to the extremely topical issue of choosing the most effective methods of teaching foreign languages to students of higher education institutions, which can provide motivation for learning a foreign language and increase students' activity. The role and importance of informational and pedagogical technologies have been determined, as well as the effectiveness and expediency of their introduction into the educational process of the educational establishment has been substantiated. The modern innovative pedagogical technologies of teaching English for future preschool teachers and primary school teachers are considered. The purpose of learning a foreign language is to form an educated person, capable of engaging in intercultural communication and solving linguistic tasks. Innovative technologies of teaching foreign languages in higher educational establishments of Ukraine are characterized. The contents of the concept of "technology" and "pedagogical technology" have been clarified. The factors that contribute to the effectiveness of foreign language training of students of pedagogical specialties are clarified and the necessity of introduction of pedagogical technologies in the process of teaching foreign languages is substantiated.

Qualitative foreign language training for students is impossible without using of innovative pedagogical technologies. Modern innovative technologies in education are the use of information and communication pedagogical technologies in the educational process, project work, work with educational computer and multimedia programs, distance technologies in learning foreign languages, creation of presentations in Microsoft PowerPoint software environment, use of Internet resources. These technologies help to implement a person-centred approach to learning, provide individualization and differentiation of learning based on students' abilities and level of knowledge. Modern pedagogical technologies, which combine the communicative and cognitive goals of foreign language training, are used for the formation of communicative competence (communicative skills formed on the basis of linguistic knowledge, skills and abilities).

Key words: foreign language teaching, foreign speech activity, teacher, university, competence, teaching, technology, pedagogical technology.

Formulation of the problem. Today, there is a steady trend towards a reorientation of the higher education system towards new values, where humanization of the pedagogical process and the democratization of interpersonal relations have become paramount.Agraduate of a higher school must be competitive, in demand on the specialty, which implies a high level of its general development, possession of information and communication competence, high professionalism, an ability to make independent decisions, innovative thinking and productive adaptation to changing. The main task of the state is to prepare highly qualified specialists who knows one or more foreign languages. Educational reforms contributes to the emergence of new teaching methods for the development of creative personality, changed the authoritarian style of educational activity on a humanistic approach taking into account the individual characteristics of the youth. Foreign language is now a means of intercultural communication, that is why the mastery of foreign language speech activity is not only aimed at development of communicative competence (language, speech, sociocultural, crosscultural etc.), but also education by means of foreign language. World changes very fast so using of new and modern pedagogical technologies are not only "trend", they are very important and necessary for educational process.

Analysis of recent research and publications. Speaking foreign language has always been one of the main tasks of methodology of teaching foreign languages. Domestic and foreign methodologists, such as G.E. Boretska, O.P Datskiv, Y.O. Dyachkova, V.L. Skalkin, A. Maley, A. Duff, A.L. Berdychevsky, N.F. Borysko, L.P. Golovanchuk, A.G. Gordeev, V.A. Maslova, V.V. Safonov, S.G. Ter-Minasov used different approaches as for teaching and learning speaking of foreign language. Researchers of scientists and requirements for knowledge of students of higher educational institutions indicate the need to improve educational process using the most effective methods and technologies of learning foreign language.

The purpose of the article. The main purpose of this work is to analyse modern pedagogical 
technologies of teaching and learning English language, to identify and disclose educational opportunities for the use of innovative technologies in teaching and learning English language for future pre-school and primary teachers in high educational establishments.

Presenting main material. Pedagogical activity should be innovative as it's one of the essential factors for the successful educational process of any educational institution. Innovative activity creates the basis for creating the competitiveness of an institution in the educational services market and on the other hand it determines the directions of professional growth of teachers or lecturers and their creative search that really contributes the personal growth of students [1]. In this regard, nowadays, the use of modern informational and pedagogical technologies in educational establishments has become increasingly widespread, representing not only modern technical means, but also new approaches to the educational process. This is due to the main purpose of teaching foreign languages: the formation and development of the communicative culture of students, their practical mastery of a foreign language. The task of the university teacher or lecturer is to create all conditions for the practical training of the language by each student. This involves the selection of such teaching methods that would allow him to show his activity and his creativity. Modern innovative technologies are related to the use of various informational and pedagogical technologies and Internet resources.

An analysis of the activities of universities shows that today ensuring of the principle of variability helps the pedagogical process be flexible to any educational model and tasks. As for the background of the development of various options for the content of education, we should identify ideas, which became the introduction of the concept of educational technology into the philosophy of education. According to the Interpretative dictionary technology is a set of techniques used in any business, skill or art. Among the large number of definitions of this concept, we should mention an interpretation of pedagogical technology proposed by B.T. Likhachev: "this is a set of psychological and pedagogical attitudes that determine a special set and layout of forms, methods, teaching methods, educational tools that form the organizational and methodological aspects of the pedagogical process" [4]. I.P. Volkov came to a conclusion that pedagogical technology is a description of the process of achieving the planned learning outcomes [2].

Proceeding from this, among the list of various pedagogical technologies, the most confidently tested by time are the following: multilevel training; cooperative learning; individual and differentiated approach; project method and others. All of them contribute to the development of innovations in education, involving the improvement of pedagogical technologies and related methods, techniques and learning tools, developing students' ability to motivate actions and to navigate independently using and analysing the information; the formation of their creative thinking and the disclosure of their natural abilities. Pedagogical technologies are associated with the widespread use of new information technologies, which make it possible to fully reveal the didactic functions of these methods and to realize the potential educational opportunities.

Since today free access to the necessary information is required, in the information centres all the opportunities are created for access to scientific, cultural and information centres around the world in order to form their own independent opinion as a part of educational process according to the tasks. Thus, students should be provided with favourable conditions for using the technological capabilities of modern means of communication both for searching and receiving information, and for developing cognitive and communicative abilities and developing their ability to make decisions quickly in difficult situations. This process proceeds more successfully using informational and communicational training technologies, including specific methods and technical means (computers, audioand video, telecommunication networks, etc.) for working with information. Today, this type of pedagogical technologies is designated by the term "computer technology of instruction", which continues to develop the ideas of programmed instruction, opening up new technological possibilities of educational process with advantages connected with computers and telecommunications.

According to the latest data provided, in particular, by the Internet, currently all universities in Ukraine use innovative technologies during educational process (seminars and conferences). They are attended by both specialists of higher education institutions and teachers of secondary schools. All the types of educational establishments that use innovative technologies are always open to modern scientific research. In the curriculum of such establishments we can find such forms of training as design development, training, internships in production, as well as participation in research organizations, practice of different types.

Considering the technological aspect of teaching foreign languages in pedagogical institutes and universities, we think that the most widely used are personality-oriented and informationalbased learning technologies. Personally- oriented technologies are represented by technologies of differentiation and individualization of instruction, design technologies, etc. The main forms of using information technology are:

1) multimedia English lessons (using the basis of computer training programs);

2) testing on computers;

3) English lessons on the basis of computer presentations during lectures, seminars, labs 
and students' reports. Using the PowerPoint computer program, English teachers can organize a series of multimedia lessons, training modules, electronic study guides that allow students to integrate audiovisual information presented in various forms graphics, slides, text, video, chat etc.;

4) telecommunication projects, work with audio and video resources online;

5) distance learning, including all forms of educational activity, carried out without personal contact of the teacher or lecture and student. Almost any educational services are presented on the global Internet today, from short-term continuing education courses to comprehensive higher education programs;

6) using of an interactive tablet Smart Board;

7) voice chat on the local network, used to teach phonetics. For the implementation of the chat, free Net Speakerphone or Speaker programs are used, which allow to communicate in any mode: teacher student, student - student, conference mode;

8) linguaphone devices, which include the teaching console and workplaces of students, as well as equipment according to one of the following schemes: audio-passive, audio-active or audiocomparative [8, p. 125]. Audio passive devices aim to provide students with the opportunity to listen to phonograms; audio-active devices allow students not only to listen to phonograms, but also to train themselves in loud speech, audio and audio devices allow you to record your speech on a tape recorder, and then listen to this recording and compare it with the example.

All this is aimed for creation of a foreign language environment in the process of teaching foreign languages and achieving of technical and informational means of instructions. Computer training programs in foreign language classes allow lecture to carry out the following forms of exercises as: pronunciation, grammar material, vocabulary, writing, teaching monologist and dialogical speech etc.

Today the priority as for searching of information is increasingly given to the Internet, which provides a wide selection of sources of information, which is so necessary in the educational process. These include basic information hosted on Web and servers on the network, information sent by e-mail, various databases of various information centres, information about books and magazines of online stores etc. Information resources of the Internet are organically integrated into the educational process, helping to solve various didactic tasks in English, such as: reading skills; replenishment of one's vocabulary of the foreign language which is being studied; improving of the writing skills; listening exercises based on the original sound texts; acquaintance with culture, speech etiquette, features of the speech behaviour of the country of the studied language; improving of monologist and dialogical speech; the formation of motivation for foreign language speech activity and knowledge of the specifics of academic writing. For solving of these problems, real conditions are created for students to expand their knowledge, self-education, and the ability to organize independent and research work.

Researcher I.G. Zakharova proposes the creation of an Internet library to facilitate Internet searches. However, for the effective operation of such a resource, it is important to prepare auxiliary pages containing the most valuable sources of information on the studied problems. It is important to understand that methodologists consider that information Internet resources on any subject contribute to the formation of communicative competence. Although these resources are not educational material, however, they provide the opportunity to work on the network with authentic texts, which is a motivational source for students, and therefore can be used in the educational process as for learning English. Therefore, the ability to see, to read and to listen to authentic material and then communicate with native speakers themselves forms an independent creativity and critical thinking.

Lecture can offer for students' electronic versions of newspapers, most of which have their own web pages such as The Times, The Guardian, The Washington Post. Online exercises with the newspaper provides unique opportunities for forming intercultural communication, when students can take part in the discussion of the problems that interest them. The purpose of teaching a foreign language in high school nowadays is to acquire students' communicative competences that allow them to realize their knowledge and skills to solve specific communication tasks in real life situations. A foreign language acts as a means of communication with representatives of other nations, and therefore a cultural or intercultural approach to learning continues to develop within the framework of the concept of "dialogue of cultures" in order to form students' multilingual literacy.

Foreign language skills are now available and will continue to be one of the top employers' requirements. Quality language training for students is not possible without the use of modern educational technologies (vocational-oriented foreign language training, project work in training, application of information and telecommunication technologies, work with computer training programs using foreign languages (multimedia system), distance technologies in learning foreign languages, use of online resources, learning a foreign language in a computer environment (forums, blogs, email).

Thus, the possibilities of using Internet resources are enormous, since they create the conditions for obtaining the necessary information for students located anywhere in the world, whether it is news from the life of young people, articles from newspapers and magazines, regional geographic materials etc.

However, it is important to understand that each teacher or lecture follows such position: the computer 
in the educational process is not a mechanical teacher; it is a tool that enhances and expands the possibilities of his educational activities. In this case, the teacher or lecture organizes the cognitive activity of students, trying to interactively use, for example, situational learning models; apply creative methods, including the latest techniques (case studies, role-playing games, business games, dialogs, disputes, seminars, conferences, abstract defence, etc.) in order to solve the problems of teaching quality using innovative teaching technologies.

Conclusions and suggestions. Modern reality makes ever higher demands on the level of practical knowledge of a foreign language. In this regard, the use of innovative educational technologies provides tremendous opportunities to increase the effectiveness of the learning process. The information and multimedia training programs considered in the article, as practice shows, have advantages over traditional teaching methods, since they not only allow to train certain types of speech activity, using them in various combinations, but also contribute to the implementation of an individual approach and increase student independence.

Innovative technologies in the process of teaching a foreign language can also qualitatively improve the general cultural development of young people, contributing to the further improvement of their computer skills. This contributes to the formation of language competencies, increase motivation in learning a foreign language. Hence, the use of innovative technologies in teaching foreign languages carries a huge pedagogical potential that allows to convert mastery of a foreign language into a living creative process.

\section{References:}

1. Борецька Г.Е. Сучасні технології формування англомовної компетенції говоріння в учнів основної і старшої школи. Іноземні мови. 2010. № 2 . С. 23-26.

2. Волков И.П. Цель одна - дорог много : Проектирование процессов обучения : книга для учителя : Из опыта работы. Москва : Просвещение, 1990. 159 с.

3. Дацків О.П. Комплекс вправ для вдосконалення фонетичних навичок говоріння у майбутніх учителів англійської мови засобами драматизації. Іноземні мови. 2014. № 2. С. 34-38.

4. Лихачев Б.Т. Педагогика. Курс лекций : учебное пособие для студентов педагогических учебных заведений и слушателей ИПК и ФПК. Москва : Прометей, Юрайт, 1998. 464 с.

5. Люта А.В. Сучасні методи вивчення іноземних мов. Держава та регіони. Серія «Гуманітарні науки». 2012. № 2. С. 98-106.

6. Скалкин В.Л. Основы обучения устной иноязычной речи. Москва : Русский язык, 1981. 248 с.

7. Щукин А.Н. Современные интенсивные методы и технологии обучения иностранным языкам : учебное пособие. Москва : Филоматис, 2008. $188 \mathrm{c}$.

8. Maley A. Drama techniques : a resource book of communication activities for language teachers. Third edition. Cambridge : Cambridge University Press, 2005. $246 \mathrm{p}$.

Терлецька Л. М. Сучасні технології навчання англійської мови студентів педагогічних спеціальностей

Статтю присвячено надзвичайно актуальному питанню вибору найефрективніших методів навчання іноземних мов студентів закладів вищої педагогічної освіти, які можуть забезпечити мотивацію вивчення іноземної мови, підвищити активність студентів. Визначено роль і значення інформаційних і педагогічних технологій, а також обгрунтовано ефективність і доцільність їх впровадження в освітній процес закладу освіти. Розглянуто сучасні інноваційні педагогічні технології навчання англійської мови майбутніх вчителів закладів дошкільної освіти й вчителів початкової школи. Метою вивчення іноземної мови є формування освіченої особистості, здатної брати участь у міжкультурній комунікації та вирішувати поставлені перед нею мовні завдання. Схарактеризовано інноваційні технології навчання іноземних мов у закладах вищої педагогічної освіти України. Уточнено зміст поняття «технологія» $i$ «педагогічна технологія». З'ясовано чинники, які сприяють ефрективності іншомовної підготовки студентів педагогічних спеціальностей та обгрунтовано необхідність впровадження педагогічних технологій у процес навчання іноземних мов.

Якісна іншомовна підготовка студентів неможлива без використання інноваційних педагогічних технологій. Сучасні інноваційні технології в освіті - це використання інформаційних і комунікаційних педагогічних технологій в освітньому процесі, проєктна робота, робота з навчальними комп'ютерними та мультимедійними програмами, дистанційні технології в навчанні іноземних мов, створення презентацій у програмному середовищі Microsoft PowerPoint, використання ресурсів мережі Iнтернет. Ці технології допомагають реалізувати особисто орієнтований підхід у навчанні, забезпечують індивідуалізацію та дифреренціацію навчання з урахуванням здібностей і рівня знань студентів. Для фоормування комунікативної компетениії (комунікативних умінь, сфоорованих на основі мовних знань, навичок та умінь) використовуються сучасні педагогічні технології, що поєднують комунікативні й пізнавальні цілі іншомовної підготовки.

Ключові слова: навчання іноземних мов, іншомовне мовлення, педагог, університет, компетенція, навчання, технологія, педагогічна технологія. 